\title{
Selectivity of HeRBicides Bentazon ANd NicosulfuRON FOR Crotalaria juncea INTERCROPPED WITH MAIZE CULTURE ${ }^{1}$
}

\author{
Seletividade dos Herbicidas Bentazon e Nicosulfuron para Crotalaria juncea em Consórcio com \\ a Cultura do Milho
}

NOGUEIRA, C.H.P. ${ }^{2}$, and CORREIA, N.M. ${ }^{3}$

\begin{abstract}
The objective was to study the selectivity of herbicides bentazon and nicosulfuron, alone and in a mixture, to Crotalaria juncea, when established in intercropping with maize, as well as weed control and maize development in this production system. Two experiments were conducted in the field, in late harvest and in harvest periods. The experimental design was a randomized block, with 14 treatments and four replicates. Eight treatments with herbicides bentazon (720 and $960 \mathrm{~g}$ a.i. ha $\mathrm{h}^{-1}$ ), nicosulfuron (16 and $48 \mathrm{~g}$ a.i. ha $\mathrm{h}^{-1}$ ) and bentazon plus nicosulfuron $\left(720+16 ; 720+48 ; 960+16 ; 960+48\right.$ g a.i. ha $\left.{ }^{-1}\right)$ were studied, besides six controls (single crop maize and sunn hemp, with and without weed control, intercropped maize and sunn hemp, with and without weed control). Herbicide bentazon alone, in both dosages evaluated, was selective to C. juncea. Nicosulfuron in the dosage of $48 \mathrm{~g}$ a.i. ha ${ }^{-1}$, alone or in a mixture with bentazon, promoted the best weed control. Maize interferes in the recoverability of sunn hemp plants treated with herbicides. C. juncea intercropped without herbicides or sprayed with bentazon negatively impacted maize yield in the harvest. The pulverization of bentazon (720 and $960 \mathrm{~g}$ a.i. ha ${ }^{-1}$ ) in late harvest and bentazon plus nicosulfuron $\left(720+16\right.$ and $920+16 \mathrm{~g}$ a.i. $\left.\mathrm{ha}^{-1}\right)$ in harvest provided the best results, considering maize yield, development and recovery of sunn hemp and weed management.
\end{abstract}

Keywords: green manure, sunn hemp, phytointoxication, interference, simultaneously sowing.

\begin{abstract}
RESUMO - Objetivou-se neste trabalho estudar a seletividade dos herbicidas bentazon e nicosulfuron, isolados e em mistura, para Crotalaria juncea, quando estabelecida em consórcio com o milho, bem como o controle de plantas daninhas e o desenvolvimento do milho nesse sistema de produção. Dois experimentos foram desenvolvidos em campo, no periodo de safrinha e no periodo de safra. $O$ delineamento experimental foi de blocos ao acaso, com 14 tratamentos e quatro repetições. Oito tratamentos com herbicidas, bentazon (720 e $960 \mathrm{~g}$ i.a. ha $\mathrm{h}^{-1}$ ), nicosulfuron (16 e $48 \mathrm{~g}$ i.a. ha $\mathrm{h}^{-1}$ ) e bentazon mais nicosulfuron $\left(720+16 ; 720+48 ; 960+16 ; 960+48\right.$ gi.a. ha $\left.{ }^{-1}\right)$, foram estudados, além de seis testemunhas (milho e crotalária solteiros, com e sem o controle de plantas daninhas; milho e crotalária em consórcio, com e sem o controle de plantas daninhas). O bentazon isolado, nas duas dosagens avaliadas, foi seletivo para C. juncea. Nicosulfuron na dosagem de $48 \mathrm{~g}$ i.a. $\mathrm{ha}^{-1}$, isolado ou em mistura com bentazon, promoveu o melhor controle das plantas daninhas. $O$ milho interfere na capacidade de recuperação das plantas de crotalária tratadas com herbicidas. C. juncea em consórcio sem herbicidas ou pulverizada com bentazon interferiu negativamente na produtividade do milho na safra. As aplicações de bentazon (720 e $960 \mathrm{~g}$ i.a. ha $\mathrm{H}^{-1}$ ), na safrinha, e de bentazon mais nicosulfuron $\left(720+16\right.$ e $920+16 \mathrm{~g}$ i.a. $\left.\mathrm{ha}^{-1}\right)$, na safra, proporcionaram os melhores resultados, considerando a produtividade do milho, o desenvolvimento e recuperação da crotalária e o manejo de plantas daninhas.
\end{abstract}

Palavras-chave: adubo verde, crotalária, fitointoxicação, interferência, semeadura simultânea.

Recebido para publicação em 27.11.2015 e aprovado em 26.2.2016.

Universidade Estadual Paulista, Jaboticabal-SP, Brasil, <nogueirachp@gmail.com>; ${ }^{3}$ Embrapa Hortaliças, Brasília-DF, Brasil. 


\section{INTRODUCTION}

Genus Crotalaria juncea (known as brown hemp, Indian hemp, Madras hemp, or sunn hemp) is one of the largest in the Fabaceae family, with about 690 species distributed in tropical and subtropical areas (Garcia et al., 2013). Among the species of importance for Brazilian agriculture, C. juncea stands out, which has widely reported benefits in agriculture such as soil nutrient input (Santos et al., 2010), straw production for direct planting (Gitti et al., 2012), weed management because of its competitive ability (Mosjidis and Wehtje, 2011) and the potential nematicide due to producing substances such as monocrotaline (Wang et al., 2002).

The cultivation of this species is therefore recommended for the crops succession/ rotation systems. Sunn hemp species also have potential for use in crops intercropping systems, especially with maize. This enables the best use of the agricultural year, having in the same period the economic return, with grain production and the benefits from this green manure (Telhado, 2007).

Maize is recommended for crops intercropping because it has competitive features such as rapid initial growth and establishment, high photosynthetic efficiency and interception of light radiation (IKEDA et al., 2013). However, when maize plants do not have favorable conditions to establish intercropping, the interlayer species can compete with the crop (Nakagawa et al., 2009; Gitti et al., 2012).

An efficient practice to avoid interference is to use selective herbicides for maize in order to inhibit growth of the interlayer species (Jakelaitis et al., 2004; Silva et al., 2014). This practice allows crops simultaneous seeding without the need to delay sowing, reducing sowing operations and, consequently, production costs (Heinrichs et al., 2002). However, it is necessary to know the selectivity of herbicides for the intercropped species, which can change due to the herbicide, dosage, stages of development and physiological and morphological factors that affect uptake, translocation and metabolism in plants (Oliveira Júnior et al., 2011).
In the literature there is little information on the selectivity of herbicides for $C$. juncea. Mosjidis and Wehtje (2011) have considered herbicides pendimethalin and imazethapyr selective when applied alone in preemergence, but in combination they have affected the production of sunn hemp dry matter. Kappes et al. (2012), when studying the application of reduced underdoses of glyphosate in C. juncea for the production of seeds, obtained reduction of plant height and increased plant branching, making them more compact for mechanical harvesting; however, the herbicide adversely affected seed production.

When considering the maize intercropping system with C. juncea, there is a lack of information on the selectivity of herbicides used in maize for the sunn hemp plants, weed management and interference of sunn hemp in the development of maize, especially when species sowing is simultaneous. Accordingly, the application of herbicides in dosages suitable to inhibit the growth of sunn hemp and control weeds without harming grains productivity is necessary.

This study was carried out based on the assumption that spraying bentazon and nicosulfuron herbicides in appropriate dosages on maize intercropped with sunn hemp inhibits the development of this one, but allows its recovery, in addition to controlling weeds without adversely affecting maize productivity. Thus, the aim here was to study the selectivity of bentazon and nicosulfuron herbicides, alone and in combination, for C. juncea, when established in partnership with maize crops, as well as weed control and the development of maize in this production system.

\section{MATERIALS AND METHODS}

Two experiments were conducted in the field in the experimental area of UNESP Universidade Estadual Paulista "Júlio de Mesquita Filho"/FCAV - Faculdade de Ciências Agrárias e Veterinárias, Jaboticabal, SP: one in the period from February 18 to July 15,2014 - late harvest $\left(21^{\circ} 14^{\prime} 36^{\prime \prime} \mathrm{S}\right.$ and $48^{\circ} 17^{\prime} 20^{\prime \prime} \mathrm{W}$, at $553 \mathrm{~m}$ of altitude); and the other in the period from $11 / 21 / 2014$ to $4 / 28$ / 2015 - harvest $\left(21^{\circ} 14^{\prime} 95^{\prime \prime} \mathrm{S}\right.$ and $48^{\circ} 17^{\prime} 08^{\prime \prime} \mathrm{W}$, 
at $574 \mathrm{~m}$ of altitude). Herbicides and dosages used in this study were selected from exploratory experiments previously carried out in pots in the same institution.

The soil was classified as clayey and very clayey, with values of organic matter of $17 \mathrm{~g} \mathrm{dm}^{-3}$ and $24 \mathrm{~g} \mathrm{dm}^{-3}$, respectively, for the harvest and late harvest experiments. Monthly totals of rainfall and the average monthly temperature during the experimental period are shown in Figure 1.

The experimental design was of randomized blocks, with 14 treatments and four replications. Eight treatments with herbicides - bentazon (720 and $960 \mathrm{~g}$ a.i. ha-1), nicosulfuron (16 and $48 \mathrm{~g}$ a.i. $\mathrm{ha}^{-1}$ ) and bentazon plus nicosulfuron $(720+16 ; 720+48$; $960+16 ; 960+48$ g a.i. ha $\left.^{-1}\right)$ - were studied, besides six controls (single crop maize and sunn hemp, with and without weed control; maize intercropped with sunn hemp, with and without weed control).
In the controls without weeds (hoed controls), tillage was done by hoeing whenever new plant emergence flow was found in the plots.

In the late harvest experiment, the plots were $14.0 \mathrm{~m}$ long and $2.28 \mathrm{~m}$ wide, containing three rows of maize and six of sunn hemp. The floor area corresponded to the central row of maize and four rows of sunn hemp by $12.0 \mathrm{~m}$ length, totaling $18.24 \mathrm{~m}^{2}$. In the harvest experiment, the plots were $12.0 \mathrm{~m}$ long and $2.28 \mathrm{~m}$ wide, with three rows of maize and six of sunn hemp. The floor area corresponded to the central row of maize and four rows of sunn hemp by $10.0 \mathrm{~m}$ length, totaling $15.2 \mathrm{~m}^{2}$.

Soil preparation was carried out in a conventional manner, with plowing and harrowing. In the late harvest experiment, on $2 / 18 / 2014$, and in the harvest experiment, on $11 / 21 / 2014$, maize (DKB 390 PRO2) was sown simultaneously to sunn hemp, spaced $0.76 \mathrm{~m}$ in inter-rows, with five to six seeds

Experiment of late harvest

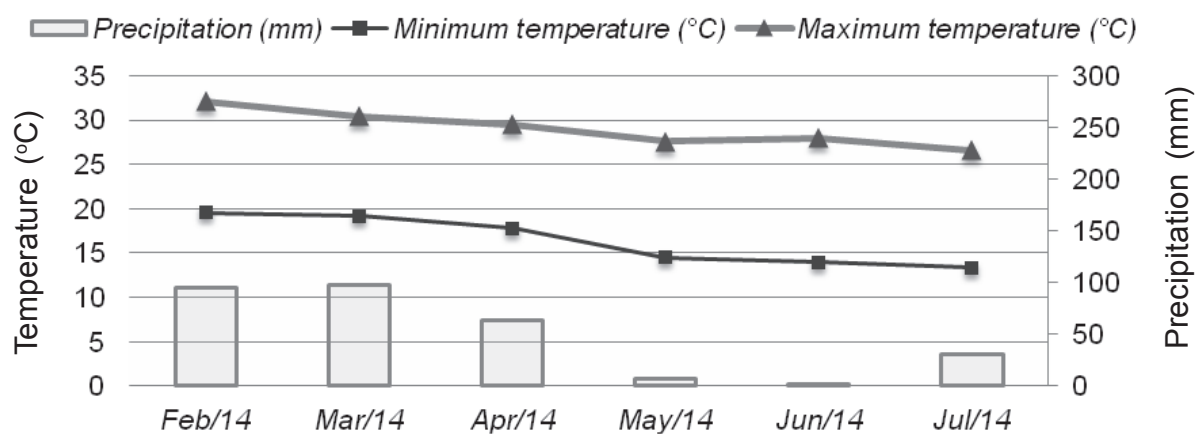

Experiment of harvest

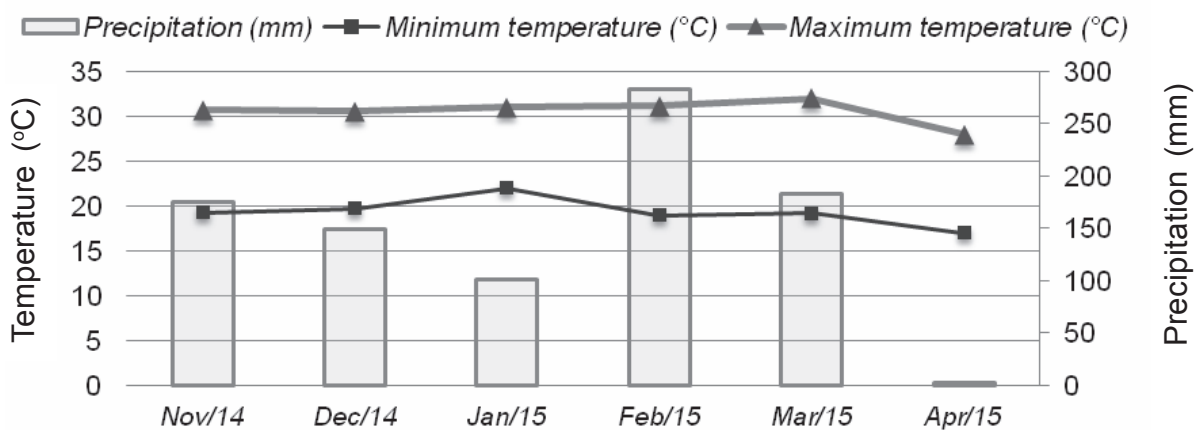

Figure 1 - Rainfall (monthly total) and average (monthly) minimum and maximum temperatures of the air recorded for the late harvest experiment, from the period from February to July 2014, and for the harvest experiment from November 2014 to April 2015. 
per meter, $5 \mathrm{~cm}$ deep. For sunn hemp, 63 seeds per meter were used, sown in double rows with $0.18 \mathrm{~m}$ of distance in inter-rows of sunn hemp and $0.29 \mathrm{~m}$ of inter-rows of sunn hemp and maize. The seeder planter used was SHM SEMEATO, model 11/13 for direct planting.

In the planting furrow, $300 \mathrm{~kg} \mathrm{ha}^{-1}$ of fertilizer formula 08-28-16 $+0.3 \%$ of $\mathrm{Zn}$ were applied. Nitrogen fertilization in mulch was done at 17 days after sowing (DAS) (stage V4V5) in the late harvest and at 25 DAS in the harvest (stage V5), in the amount of $75 \mathrm{~kg}$ ha ${ }^{1}$ of nitrogen as urea.

Herbicides in different dosages were applied with a knapsack sprayer at constant pressure maintained by compressed $\mathrm{CO}_{2}$ of $2.8 \mathrm{kgf} \mathrm{cm}^{-2}$, equipped with a XR 11002 (fan-type) flat jet four-nozzle spray boom in the late harvest and DG 11002 in the harvest, spaced $0,5 \mathrm{~m}$ and with a spray mix consumption equivalent to 150 and $200 \mathrm{~L} \mathrm{ha}^{-1}$, respectively, for late harvest and harvest. Mineral oil $0.5 \% \mathrm{v} / \mathrm{v}$ was added to all spray mixes containing bentazon.

At the time of application of the late harvest experiment, the C. juncea plants had on average 9.2 fully expanded leaves and were $18.6 \mathrm{~cm}$ high. In the harvest experiment, the plants had 11.0 fully expanded leaves and were $23.0 \mathrm{~cm}$ high. Maize was in physiological stages V4-V5 in both experiments. Eudicotyledonous weed plants had four to six true leaves, and the monocotyledonous ones (grass) even a tiller.

The weed community of the late harvest experiment consisted of six eudicotyledons and five monocotyledons species, distributed in 11 genera [Alternanthera tenella (generally known as joyweeds, or Joseph's coat), Amaranthus viridis (commonly known as slender amaranth or green amaranth), Cenchrus echinatus (common names include southern sandspur, southern sandbur), Commelina benghalensis (Benghal dayflower), Cyperus rotundus (Coco-grass, Java grass, nut grass, purple nut sedge or purple nutsedge, red nut sedge, Khmer kravanh chruk), Eleusine indica (Indian goosegrass), Indigofera hirsuta (hairy indigo, rough hairy indigo), Ipomoea grandifolia (morning glory), Panicum maximum (guinea grass or green panic grass), Raphanus raphanistrum (wild radish) and Xantium strumarium (rough cocklebur, clotbur, common cocklebur, large cocklebur, woolgarie bur)]. The main species were A. tenella, C. echinatus, C. rotundus, $C$. benghalensis and $R$. raphanistrum.

In the harvest experiment, ten eudicotyledonous and three monocotyledonous species were identified, distributed in 12 genera [Alternanthera tenella (generally known as joyweeds, or Joseph's coat), Amaranthus retroflexus (several common names, including red-root amaranth, redroot pigweed, red-rooted pigweed, common amaranth, pigweed amaranth, and common tumbleweed), Cenchrus echinatus(common names southern sandbur, spiny sandbur, southern sandspur), Commelina benghalensis (Benghal dayflower), Eleusine indica (Indian goosegrass), Indigofera hirsuta (hairy indigo, rough hairy indigo), Ipomoea grandifolia (morning glory), Ipomoea quamoclit (cypress vine, cypressvine morning glory, cardinal creeper, cardinal vine, star glory or hummingbird vine), Phyllanthus niruri (known by the common names gale of the wind, stonebreaker or seed-under-leaf), Portulaca oleracea (purslane, also known as verdolaga, pigweed, little hogweed, red root, pursley, and moss rose), $R$. raphanistrum (wild radish or jointed charlock), Richardia brasiliensis (Tropical Mexican clover) and Xanthium strumarium (rough cocklebur, clotbur, common cocklebur, large cocklebur, woolgarie bur)]. The main species was A. tenella.

Every week, there were visual assessments of weed controls. However, the data presented refer to 17 and 45 days after application (DAA) of herbicides in the late harvest experiment and at 14 DAA in the harvest experiment. A ranking scale from 0 to $100 \%$ was used, where zero is the absence of visual damage and 100 is plant death (SBCPD, 1995). In both experiments, at 48 DAA, plants shoots in two areas of $0.45 \mathrm{~m}^{2}$ each, randomly chosen within the floor area of the plots, was collected, and the material dried in an oven with forced air circulation until reaching constant weight, when the dry matter was quantified.

Possible visual damage in plants of C. juncea were evaluated at 10,17 and 45 DAA of the herbicides and at 7, 14 and 42 DAA, respectively, for the late harvest and harvest 
experiments, assigning ranking grades in percent, where zero corresponds to the absence of visual symptoms and 100 corresponds to plant death.

The stand (in two central rows per $2.0 \mathrm{~m}$ length), the height of 10 sunn hemp plants (in sequence in the row) and the dry matter were determined at 94 DAA, in both experiments. To determine the dry matter, the shoots of the sunn hemp plants in four areas of $0.19 \mathrm{~m}^{2}$ each, chosen in the floor area of the plot, were collected and dried in an oven with forced air circulation until reaching constant weight, when they were assessed. The data were estimated in $\mathrm{kg} \mathrm{ha}^{-1}$.

In maize, the stand was evaluated (in the center row by $2.0 \mathrm{~m}$ length) and height of 10 plants at 117 DAA in the late harvest experiment and $132 \mathrm{DAA}$ in the harvest experiment. As for the height, the distance of the plant from the base to the insertion of the tassel was measured in 10 plants in a row (in the sequence). At 147 and 158 DAS, in the late harvest and harvest experiments, respectively, harvesting of maize kernels was carried out. For this, the ears of the center row were manually harvested by $12.0 \mathrm{~m}$ length in the late harvest experiment, and $10.0 \mathrm{~m}$ length in the harvest experiment. Then the ears were mechanically threshed and grain moisture was corrected to $13.0 \%$. Production data per plot were estimated in $\mathrm{kg} \mathrm{ha}^{-1}$ to obtain grain yield. The mass of 400 grains was also determined.

The data were submitted to the F-test of analysis of variance. The effects of the treatments with herbicide and controls, when significant, were compared by the Tukey's test at $5 \%$ probability. For the weeds dry matter, data were turned into $\log (x+1)$.

\section{RESULTS AND DISCUSSION}

Both in the late harvest as in the harvest experiments there was a significant treatment effect in all control evaluation times and dry matter of the shoots of the weeds (Tables 1 and 2).

In both experiments, in the two evaluation periods, nicosulfuron herbicide at the highest dosage (48 $g$ a.i. ha ${ }^{-1}$ ), alone or combined with bentazon, resulted in a higher percentage of weed control, including mixing bentazon plus nicosulfuron $960+16 \mathrm{~g}$ a.i, ha ${ }^{-1}$ in the group

Table 1 - Percent of control of weeds at 17 and 45 days after application (DAA) of the herbicides and dry matter of the shoots at 48 DAA in the maize crop intercropped with Crotalaria juncea, besides the controls without application of herbicide - late harvest experiment

\begin{tabular}{|c|c|c|c|c|}
\hline \multirow{2}{*}{ Herbicides/controls ${ }^{\underline{1}}$} & \multirow{2}{*}{$\begin{array}{l}\text { Dosing } \\
\left(\mathrm{g} \mathrm{ha}^{-1}\right)\end{array}$} & \multicolumn{2}{|c|}{ Control $(\%)-$ daa } & \multirow{2}{*}{$\begin{array}{l}\text { Dry matter }{ }^{2 /} \\
\quad\left(\mathrm{g} \mathrm{m}^{-1}\right)\end{array}$} \\
\hline & & 17 & 45 & \\
\hline 1. Bentazon & 720 & $3.8 \mathrm{c}$ & $0.0 \mathrm{~d}$ & $0.7 \mathrm{abcd}$ \\
\hline 2. Bentazon & 960 & $7.5 \mathrm{c}$ & $10.0 \mathrm{~cd}$ & $0.6 \mathrm{abcd}$ \\
\hline 3. Nicosulfuron & 16 & $23.8 \mathrm{~b}$ & $45.0 \mathrm{bc}$ & $0.8 \mathrm{abc}$ \\
\hline 4. Nicosulfuron & 48 & $47.5 \mathrm{a}$ & $78.8 \mathrm{ab}$ & $0.2 \mathrm{~cd}$ \\
\hline 5. Bentazon + nicosulfuron & $720+16$ & $18.8 \mathrm{bc}$ & $41.3 \mathrm{c}$ & $0.3 \mathrm{bcd}$ \\
\hline 6. Bentazon + nicosulfuron & $720+48$ & $52.5 \mathrm{a}$ & $80.0 \mathrm{ab}$ & $0.4 \mathrm{abcd}$ \\
\hline 7. Bentazon + nicosulfuron & $960+16$ & $27.5 \mathrm{~b}$ & $42.5 \mathrm{c}$ & $0.2 \mathrm{bcd}$ \\
\hline 8. Bentazon + nicosulfuron & $960+48$ & $47.5 \mathrm{a}$ & $81.3 \mathrm{a}$ & $0.2 \mathrm{~d}$ \\
\hline \multicolumn{2}{|l|}{ 9. Intercropping with weeds } & 0.0 & 0.0 & $0.6 \mathrm{abcd}$ \\
\hline \multicolumn{2}{|l|}{ 10. Maize with weeds } & 0.0 & 0.0 & $1.0 \mathrm{a}$ \\
\hline \multicolumn{2}{|l|}{ 11. Sunn hemp with weeds } & 0.0 & 0.0 & $0.9 \mathrm{ab}$ \\
\hline \multicolumn{2}{|l|}{$\mathrm{CV}$} & $23.9 * *$ & $31.3 * *$ & $45.2 * *$ \\
\hline \multicolumn{2}{|l|}{ LSD } & 16.2 & 35.2 & 0.6 \\
\hline
\end{tabular}

${ }^{1 /}$ The control notes of the controls without application were not included in the statistical analyses. ${ }^{2}$ The data for dry matter were turned into a $\log (x+1)$. Means followed by the same letter do not differ statistically from each other by the Tukey's test at $5 \%$ probability. ** Significant at $1 \%$ probability by the $\mathrm{F}$ test of the analysis of variance. 
Table 2 - Percent of control of weeds at 14 and 42 days after application (DAA) of the herbicides and dry matter of the shoots at 48 DAA in the maize crop intercropped with Crotalaria juncea, besides the controls without application of herbicide - harvest experiment

\begin{tabular}{|c|c|c|c|c|}
\hline \multirow{2}{*}{ Herbicides/controls ${ }^{\underline{1}}$} & \multirow{2}{*}{$\begin{array}{l}\text { Dosing } \\
\left(\mathrm{g} \mathrm{ha}^{-1}\right)\end{array}$} & \multicolumn{2}{|c|}{ Control (\%) - DAA } & \multirow{2}{*}{$\begin{array}{c}\text { Dry matter }{ }^{2 /} \\
\left(\mathrm{g} \mathrm{m}^{-1}\right)\end{array}$} \\
\hline & & 14 & 42 & \\
\hline 1. Bentazon & 720 & $3.1 \mathrm{c}$ & $11.3 \mathrm{c}$ & $1.0 \mathrm{abc}$ \\
\hline 2. Bentazon & 960 & $1.9 \mathrm{c}$ & $8.1 \mathrm{c}$ & $0.8 \mathrm{abc}$ \\
\hline 3. Nicosulfuron & 16 & $37.5 \mathrm{~b}$ & $42.5 \mathrm{~b}$ & $1.2 \mathrm{abc}$ \\
\hline 4. Nicosulfuron & 48 & $72.5 \mathrm{a}$ & $88.1 \mathrm{a}$ & $0.9 \mathrm{abc}$ \\
\hline 5. Bentazon + nicosulfuron & $720+16$ & $39.4 \mathrm{~b}$ & $38.8 \mathrm{~b}$ & $1.0 \mathrm{abc}$ \\
\hline 6. Bentazon + nicosulfuron & $720+48$ & $73.8 \mathrm{a}$ & $83.8 \mathrm{a}$ & $0.7 \mathrm{c}$ \\
\hline 7. Bentazon + nicosulfuron & $960+16$ & $57.5 \mathrm{ab}$ & $69.4 \mathrm{a}$ & $0.8 \mathrm{c}$ \\
\hline 8. Bentazon + nicosulfuron & $960+48$ & $78.1 \mathrm{a}$ & $79.4 \mathrm{a}$ & $0.8 \mathrm{bc}$ \\
\hline \multicolumn{2}{|l|}{ 9. Intercropping with weeds } & 0.0 & 0.0 & $1.2 \mathrm{abc}$ \\
\hline \multicolumn{2}{|l|}{ 10. Maize with weeds } & 0.0 & 0.0 & $1.6 \mathrm{a}$ \\
\hline \multicolumn{2}{|l|}{ 11. Sunn hemp with weeds } & 0.0 & 0.0 & $1.5 \mathrm{ab}$ \\
\hline \multicolumn{2}{|l|}{$\mathrm{CV}$} & $23.9 * *$ & $15.2 * *$ & $28.7 * *$ \\
\hline \multicolumn{2}{|l|}{ LSD } & 25.8 & 19.0 & 0.7 \\
\hline
\end{tabular}

$1 /$ The control notes of the controls without application were not included in the statistical analyses. 2 The data for dry matter were turned into a $\log (x+1)$. Means followed by the same letter do not differ statistically from each other by the Tukey's test at $5 \%$ probability. ** Significant at $1 \%$ probability by the $\mathrm{F}$ test of the analysis of variance.

of the most effective treatments for harvest experiment. Bentazon alone, in both dosages tested, promoted the lowest control ranking grades.

Unsatisfactory results of weed control by bentazon were also reported by Ferreira et al. (1998) for A. tenella, I. hirsuta and $C$. benghalensis. However, this herbicide promoted the adequate control of Acanthospermum hispidum, Bidens pilosa and Galinsoga parviflora in the dosage of $840 \mathrm{~g}$ a.i. ha ${ }^{-1}$ (Fontes, et al., 2001); and Cyperus difformis in the dosage of $600 \mathrm{~g}$ a.i. ha ${ }^{-1}$ (Galon et al., 2008). For nicosulfuron, Timossi and Freitas (2011) have obtained satisfactory results in weed control in maize with the dosage of $60 \mathrm{~g}$ a.i. ha ${ }^{-1}$ in an isolated application and with 20 and $40 \mathrm{~g}$ a.i. ha ${ }^{-1}$ in association with atrazine.

The lowest mass accumulation by weeds in the the harvest experiment was obtained with bentazon plus nicosulfuron $(960+48 \mathrm{~g}$ a.i. ha-1), differing only from the nicosulfuron treatments at the lowest dosage and single maize and sunn hemp with weeds. In the harvest experiment, the mixtures bentazon plus nicosulfuron in dosages $960+16$ and $720+48$ g a.i. ha ${ }^{-1}$ resulted in lower dry matter, differing only from single maize and sunn hemp with weeds.

Among the controls without herbicide application, in both experiments, in single maize there was greater mass accumulation by the weeds, not differing from single sunn hemp and in intercropping with maize. The latter has not differed from the herbicide treatments. The effect observed can be explained by the fact that the sunn hemp plants, added to maize, promoted rapid shading of the area, interfering with the development of weeds. Mosjidis and Wehtje (2011) have reported a reduction of up to $96 \%$ biomass of weeds with increasing seeding density of C. juncea, justified by the rapid growth and plant height of this species. Timossi et al. (2011) have mentioned that C. juncea, grown in autumn-winter, had a suppressive effect on the establishment of weeds.

The treatments studied significantly affected all variables assessed in the sunn hemp plants in both experiments (Tables 3 and 4).

In the late harvest experiment, treatments with herbicides caused severe visual damage to sunn hemp plants. At 10 
Table 3 - Phytointoxication notes obtained at 10, 17 and 45 days after application (DAA) of the herbicides in Crotalaria juncea, as well as the population of plants, height and dry matter of the shoots at 94 DAA, when intercropped with the maize crop, besides the controls without application of herbicide - late harvest experiment

\begin{tabular}{|c|c|c|c|c|c|c|c|}
\hline \multirow{2}{*}{ Herbicides/controls ${ }^{1 /}$} & \multirow{2}{*}{$\begin{array}{l}\text { Dosing } \\
\left(\mathrm{g} \mathrm{ha}^{-1}\right)\end{array}$} & \multicolumn{3}{|c|}{ Phytointoxication $(\%)-$ DAA } & \multirow{2}{*}{$\begin{array}{l}\text { Population } \\
\text { (a thousand } \\
\text { plants }^{-1} \mathrm{~h}^{-1} \text { ) }\end{array}$} & \multirow{2}{*}{$\begin{array}{l}\text { Height } \\
\text { (m) }\end{array}$} & \multirow{2}{*}{$\begin{array}{c}\text { Dry } \\
\text { matter } \\
\left(\mathrm{kg} \mathrm{ha}^{-1}\right)\end{array}$} \\
\hline & & 10 & 17 & 45 & & & \\
\hline 1. Bentazon & 720 & $53.8 \mathrm{c}$ & $22.5 \mathrm{~d}$ & $16.3 \mathrm{~d}$ & $46.0 \mathrm{c}$ & $1.3 \mathrm{bc}$ & $329.9 \mathrm{~d}$ \\
\hline 2. Bentazon & 960 & $77.5 \mathrm{ab}$ & $48.0 \mathrm{c}$ & $36.3 \mathrm{c}$ & $26.3 \mathrm{c}$ & $1.2 \mathrm{c}$ & $330.9 \mathrm{~d}$ \\
\hline 3. Nicosulfuron & 16 & $53.8 \mathrm{c}$ & $60.0 \mathrm{bc}$ & $98.0 \mathrm{a}$ & $0.0 \mathrm{c}$ & $0.0 \mathrm{~d}$ & $0.0 \mathrm{~d}$ \\
\hline 4. Nicosulfuron & 48 & $62.5 \mathrm{bc}$ & $62.5 \mathrm{bc}$ & $95.3 \mathrm{a}$ & $0.0 \mathrm{c}$ & $0.0 \mathrm{~d}$ & $0.0 \mathrm{~d}$ \\
\hline 5. Bentazon + nicosulfuron & $720+16$ & $75.0 \mathrm{abc}$ & $69.5 \mathrm{ab}$ & $74.5 \mathrm{~b}$ & $6.6 \mathrm{c}$ & $0.1 \mathrm{~d}$ & $143.1 \mathrm{~d}$ \\
\hline 6. Bentazon + nicosulfuron & $720+48$ & $78.8 \mathrm{ab}$ & $73.3 \mathrm{ab}$ & $97.5 \mathrm{a}$ & $0.0 \mathrm{c}$ & $0.0 \mathrm{~d}$ & $0.0 \mathrm{~d}$ \\
\hline 7. Bentazon + nicosulfuron & $960+16$ & $78.8 \mathrm{ab}$ & $70.8 \mathrm{ab}$ & $85.0 \mathrm{ab}$ & $19.7 \mathrm{c}$ & $0.2 \mathrm{~d}$ & $92.2 \mathrm{~d}$ \\
\hline 8. Bentazon + nicosulfuron & $960+48$ & $86.5 \mathrm{a}$ & $84.5 \mathrm{a}$ & $94.8 \mathrm{a}$ & $0.0 \mathrm{c}$ & $0.0 \mathrm{~d}$ & $0.0 \mathrm{~d}$ \\
\hline \multicolumn{2}{|l|}{ 9. Intercropping with weeds } & 0.0 & 0.0 & 0.0 & $486.8 \mathrm{~b}$ & $1.7 \mathrm{ab}$ & $2910.9 \mathrm{c}$ \\
\hline \multicolumn{2}{|l|}{ 10. Intercropping with weeds } & 0.0 & 0.0 & 0.0 & $523.0 \mathrm{~b}$ & $1.7 \mathrm{ab}$ & $2969.9 \mathrm{c}$ \\
\hline \multicolumn{2}{|l|}{ 11. Sunn hemp with weeds } & 0.0 & 0.0 & 0.0 & $1095.4 \mathrm{a}$ & $1.8 \mathrm{a}$ & $6378.9 \mathrm{a}$ \\
\hline \multicolumn{2}{|l|}{ 12. Intercropping with weeds } & 0.0 & 0.0 & 0.0 & $1138.2 \mathrm{a}$ & $1.7 \mathrm{a}$ & $5115.1 \mathrm{~b}$ \\
\hline \multicolumn{2}{|l|}{$\mathrm{CV}$} & $13.1 * *$ & $13.1 * *$ & $8.8^{* *}$ & $42.4 * *$ & $23.0^{* *}$ & $24.1 * *$ \\
\hline \multicolumn{2}{|l|}{ LSD } & 22.4 & 19.1 & 15.6 & 292.9 & 0.5 & 909.2 \\
\hline
\end{tabular}

1/ The phytointoxication notes of the controls without application were not included in the statistical analyses. Means followed by the same letter do not differ statistically from each other by the Tukey's test at $5 \%$ probability. ${ }^{*}$ Significant at $1 \%$ probability by the $\mathrm{F}$ test of the analysis of variance.

Table 4 - Phytointoxication notes obtained at 7, 14 and 42 days after application (DAA) of the herbicides in Crotalaria juncea, as well as the population of plants, height and dry matter of the shoots at 94 DAA, when intercropped with the maize crop, besides the controls without application of herbicide - harvest experiment

\begin{tabular}{|c|c|c|c|c|c|c|c|}
\hline \multirow{2}{*}{ Herbicides/controls ${ }^{1}$ / } & \multirow{2}{*}{$\begin{array}{l}\text { Dosing } \\
\left(\mathrm{g} \mathrm{ha}^{-1}\right)\end{array}$} & \multicolumn{3}{|c|}{ Phytointoxication $(\%)-\mathrm{DAA}$} & \multirow{2}{*}{$\begin{array}{l}\text { Population } \\
\text { (a thousand } \\
\text { plants } \mathrm{ha}^{-1} \text { ) }\end{array}$} & \multirow{2}{*}{$\begin{array}{l}\text { Height } \\
\text { (m) }\end{array}$} & \multirow{2}{*}{$\begin{array}{c}\text { Dry matter } \\
\left(\mathrm{kg} \mathrm{ha}^{-1}\right)\end{array}$} \\
\hline & & 7 & 14 & 42 & & & \\
\hline 1. Bentazon & 720 & $4.4 \mathrm{e}$ & $3.6 \mathrm{c}$ & $3.8 \mathrm{~d}$ & $753.3 \mathrm{abc}$ & $2.3 \mathrm{a}$ & $7601.4 \mathrm{c}$ \\
\hline 2. Bentazon & 960 & $9.4 \mathrm{e}$ & $3.6 \mathrm{c}$ & $5.3 \mathrm{~d}$ & $605.7 \mathrm{~cd}$ & $2.4 \mathrm{a}$ & $7740.1 \mathrm{c}$ \\
\hline 3. Nicosulfuron & 16 & $50.6 \mathrm{~d}$ & $44.0 \mathrm{~b}$ & $41.3 \mathrm{c}$ & $437.5 \mathrm{de}$ & $1.3 \mathrm{bc}$ & $937.6 \mathrm{~d}$ \\
\hline 4. Nicosulfuron & 48 & $62.5 \mathrm{abc}$ & $70.3 \mathrm{a}$ & $85.9 \mathrm{a}$ & $82.2 \mathrm{f}$ & $0.7 \mathrm{~d}$ & $314.0 \mathrm{~d}$ \\
\hline 5. Bentazon + nicosulfuron & $720+16$ & $56.3 \mathrm{~cd}$ & $50.0 \mathrm{~b}$ & $36.7 \mathrm{c}$ & $450.7 \mathrm{de}$ & $1.6 \mathrm{bc}$ & $1833.1 \mathrm{~d}$ \\
\hline 6. Bentazon + nicosulfuron & $720+48$ & $68.1 \mathrm{ab}$ & $72.3 \mathrm{a}$ & $70.6 \mathrm{~b}$ & $269.7 \mathrm{ef}$ & $1.0 \mathrm{~cd}$ & $450.3 \mathrm{~d}$ \\
\hline 7. Bentazon + nicosulfuron & $960+16$ & $57.5 \mathrm{bcd}$ & $43.8 \mathrm{~b}$ & $33.6 \mathrm{c}$ & $532.9 \mathrm{~d}$ & $1.6 \mathrm{~b}$ & $1850.7 \mathrm{~d}$ \\
\hline 8. Bentazon + nicosulfuron & $960+48$ & $69.4 \mathrm{a}$ & $64.5 \mathrm{a}$ & $72.0 \mathrm{~b}$ & $305.9 \mathrm{e}$ & $1.1 \mathrm{~cd}$ & $781.0 \mathrm{~d}$ \\
\hline \multicolumn{2}{|l|}{ 9. Intercropping with weeds } & 0.00 & 0.0 & 0.0 & $763.2 \mathrm{abc}$ & $2.6 \mathrm{a}$ & $8260.3 \mathrm{bc}$ \\
\hline \multicolumn{2}{|l|}{ 10. Intercropping with weeds } & 0.00 & 0.0 & 0.0 & $641.5 \mathrm{bcd}$ & $2.6 \mathrm{a}$ & $8230.3 \mathrm{bc}$ \\
\hline \multicolumn{2}{|l|}{ 11. Sunn hemp with weeds } & 0.00 & 0.0 & 0.0 & $819.1 \mathrm{ab}$ & $2.6 \mathrm{a}$ & $10534.2 \mathrm{ab}$ \\
\hline \multicolumn{2}{|l|}{ 12. Intercropping with weeds } & 0.00 & 0.0 & 0.0 & $944.1 \mathrm{a}$ & $2.6 \mathrm{a}$ & $12620.7 \mathrm{a}$ \\
\hline \multicolumn{2}{|l|}{$\mathrm{CV}$} & $10.1^{* *}$ & $12.5^{* *}$ & $11.2^{* *}$ & $15.0^{* *}$ & $10.5^{* *}$ & $19.3^{* *}$ \\
\hline \multicolumn{2}{|l|}{ LSD } & 11.3 & 13.0 & 11.6 & 204.6 & 0.5 & 2439.6 \\
\hline
\end{tabular}

1/ The phytointoxication notes of the controls without application were not included in the statistical analyses. Means followed by the same letter do not differ statistically from each other by the Tukey's test at $5 \%$ probability. ** Significant at $1 \%$ probability by the F test of the analysis of variance. 
and $17 \mathrm{DAA}$, the mixture bentazon plus nicosulfuron $\left(960+48 \mathrm{~g}\right.$ a.i. $\left.\mathrm{ha}^{-1}\right)$ resulted in higher phytointoxication, differing only from nicosulfuron alone, in both dosages; and bentazon, in both dosages at 17 DAA and in the lowest dosage at 10 DAA. At 45 DAA, the ranking grades for phytotoxicity were higher than $70 \%$, except for bentazon alone, which caused visual impairment of 16.2 to $36.2 \%$ due to dosage sprayed. The nicosulfuron alone treatments, in both dosages, and bentazon plus nicosulfuron $\left(720+48\right.$ and $960+48$ g a.i. ha $\left.^{-1}\right)$ resulted in the death of all plants of the plots.

For the plant population, height and dry matter of the shoots, there was no significant difference between treatments with herbicides, except for plant height, where bentazon alone (in both dosages) differed from the other treatments with herbicides. Among the controls, single sunn hemp with and without weeds accumulated higher dry matter, with a decrease of almost $50 \%$ in mass production when comparing intercropping with monocropping.

In the harvest experiment, in general, herbicides again promoted reductions in the characteristics assessed but less pronounced than in the late harvest experiment. Herbicide bentazon alone resulted in lower visual damage and consequently higher values in the plant population, height and dry matter of the shoots, compared to the other treatments with herbicides. Therefore, bentazon in dosages 720 and $960 \mathrm{~g}$ a.i. ha ${ }^{-1}$ was the most selective herbicide for sunn hemp plants in summer conditions (harvest). In this experiment, the mass production by sunn hemp plants intercropped with maize was $28.8 \%$ lower than the monocropping production.

In the late harvest experiment, phytointoxication symptoms caused by bentazon started with chlorosis, rapidly proceeding to necrosis of the leaves, especially in places that received the spray jet. In the harvest experiment, this herbicide did not cause visual damage, such as chlorosis or necrosis, but affected plant height. Nicosulfuron promoted mild chlorosis of the leaves, less intense than bentazon, but evenly distributed in the leaves, besides necrosis of the apical meristem. This effect resulted in a clear inhibition of the plants growth.

Plants tolerant to herbicides bentazon and nicosulfuron have the same detoxification mechanisms through the action of cytochrome P450 monooxygenase, in relation to hydroxylation and glycosylation reactions (Gronwald and Connelly, 1991; Fonne-Pfister et al., 1990; Brow, 1990). Even when attached, these molecules compete for the same site, which may result in increased phytotoxicity in plants, as reported by Hinz et al. (1997), who found that bentazon and primisulfuron in cytochrome $\mathrm{P} 450$ reduced hydroxylation reactions of nicosulfuron, increasing phytotoxicity of this herbicide. However, these effects were not observed in this study because nicosulfuron alone, especially in the highest dose tested, provided greater or equal poisoning of sunn hemp plants compared to its mixture with bentazon.

The greater water availability during the harvest experiment, compared to the late harvest experiment (Figure 1), contributed to the recovery of $C$. juncea from the toxic effects of the herbicides, in addition to the intrinsic characteristics of the species, such as increased vegetative growth in the spring-summer period. In the late harvest experiment, in which water conditions were limited, the legume resilience was lower, be it due to the application of the herbicide or to the competition of intercropped maize.

Among the controls, the competition of maize plants with $C$. juncea was clear because in intercropping there was a lower plant population and accumulation of dry matter compared to the single sunn hemp controls, regardless of the presence or absence of weeds. The competitiveness of maize is due to its rapid growth and leaf architecture that result in rapid shading of rows, coupled with its higher photosynthetic efficiency (C4 metabolism) in relation to the plants of $\mathrm{C} 3$ metabolism (Santos et al., 2014), such as sunn hemp.

In the harvest experiment, single sunn hemp without weeds produced on average $7.5 \mathrm{t} \mathrm{ha}^{-1}$ of dry matter more than in the late harvest experiment plants. This fact is justified by the increased water availability in 
the harvest and sunn hemp response to the photoperiod. This is considered a short-day plant, wherein the elongation of nights favors the induction of flowering, promoting lower vegetative growth. Amabile et al. (2000) have noticed that $C$. juncea sown in January, March and November produced 7.8, 5.9 and 17.0 t ha ${ }^{-1}$ of dry matter, respectively.

Herbicide treatments, alone or in mixtures, have not caused visual damage to maize plants in both experiments.

In the late harvest experiment there was no difference between the treatments studied for the population of plants and mass of 400 grains of maize (Table 5). However, the treatments differed in grain yield. Maize plants intercropped with sunn hemp in the presence of weeds had lower productivity, differing from single maize with weeds and bentazon plus nicosulfuron in dosages $720+16,960+16$ and $960+48 \mathrm{~g}$ a.i. ha ${ }^{-1}$.

In the harvest experiment there was a significant effect of the treatments in the three traits evaluated in maize plants (Table 6). Treatments with bentazon alone, $960 \mathrm{~g}$ a.i. ha ${ }^{-1}$ and intercropping without weeds resulted in lower mass of 400 grains. This bentazon dosage has also resulted in a lower plant population, in contrast to treatments with nicosulfuron alone at $48 \mathrm{~g}$ a.i. $\mathrm{ha}^{-1}$ and single crop maize without weeds, which promoted a higher population and mass of 400 grains, respectively.

The application of bentazon alone in both dosages and maize intercropping with C. juncea, with and without weeds, resulted in lower productivity of maize, differing from the other treatments. This effect is explained by the interference of sunn hemp plants on maize, which is the result of the low suppressive effect of bentazon in the development of the legume plants in their isolated treatments.

Maize could not shade sunn hemp plants with the same efficiency as in other intercropping systems, competing mainly for light. Gitti et al. (2012), when testing C. juncea and C. spectabilis sown at different times, depending on the vegetative stage of maize, reported that $C$. juncea, simultaneously sown to maize in the summer negatively affected the productivity of maize grains.

In this study, the competition between the plants was higher in the harvest experiment

Table 5 - Population of plants at 117 days after application (DAA) of the herbicides, mass of 400 grains and yield of maize grains intercropped with Crotalaria juncea, besides the controls without application of herbicide - late harvest experiment

\begin{tabular}{|c|c|c|c|c|}
\hline Herbicides/controls & $\begin{array}{l}\text { Dosing } \\
\left(\mathrm{g} \mathrm{ha}^{-1}\right)\end{array}$ & $\begin{array}{c}\text { Population } \\
\text { (a thousand plants } \mathrm{ha}^{-1} \text { ) }\end{array}$ & $\begin{array}{c}\text { Mass of } 400 \\
\text { grains }(\mathrm{g})\end{array}$ & $\begin{array}{c}\text { Yield } \\
\left(\mathrm{kg} \mathrm{ha}^{-1}\right)\end{array}$ \\
\hline 1. Bentazon & 720 & $62.8 \mathrm{a}$ & $116.5 \mathrm{a}$ & $5141 \mathrm{ab}$ \\
\hline 2. Bentazon & 960 & $58.1 \mathrm{a}$ & $111.9 \mathrm{a}$ & $5753 \mathrm{ab}$ \\
\hline 3. Nicosulfuron & 16 & $63.3 \mathrm{a}$ & $111.5 \mathrm{a}$ & $5794 \mathrm{ab}$ \\
\hline 4. Nicosulfuron & 48 & $53.2 \mathrm{a}$ & $115.7 \mathrm{a}$ & $5488 \mathrm{ab}$ \\
\hline 5. Bentazon + nicosulfuron & $720+16$ & $65.8 \mathrm{a}$ & $109.8 \mathrm{a}$ & $6016 \mathrm{a}$ \\
\hline 6. Bentazon + nicosulfuron & $720+48$ & $62.8 \mathrm{a}$ & $111.4 \mathrm{a}$ & $5708 \mathrm{ab}$ \\
\hline 7. Bentazon + nicosulfuron & $960+16$ & $63.6 \mathrm{a}$ & $113.6 \mathrm{a}$ & $5944 \mathrm{a}$ \\
\hline 8. Bentazon + nicosulfuron & $960+48$ & $63.1 \mathrm{a}$ & $114.5 \mathrm{a}$ & $6165 \mathrm{a}$ \\
\hline 9. Maize with weeds & & $63.1 \mathrm{a}$ & $111.1 \mathrm{a}$ & $6061 \mathrm{a}$ \\
\hline 10. Maize with weeds & & $57.0 \mathrm{a}$ & $113.4 \mathrm{a}$ & $5396 \mathrm{ab}$ \\
\hline 11. Intercropping with weeds & & $59.5 \mathrm{a}$ & $108.6 \mathrm{a}$ & $3623 \mathrm{~b}$ \\
\hline 12. Intercropping with weeds & & $58.4 \mathrm{a}$ & $112.4 \mathrm{a}$ & $4174 \mathrm{ab}$ \\
\hline $\mathrm{CV}$ & & $13.1^{\mathrm{ns}}$ & $4.5^{\mathrm{ns}}$ & $16.2 * *$ \\
\hline LSD & & 19.9 & 12.6 & 2181.9 \\
\hline
\end{tabular}

Means followed by the same letter do not differ statistically from each other by the Tukey's test at 5\% probability. ** Significant at $1 \%$ probability by the $\mathrm{F}$ test of the analysis of variance. ${ }^{\mathrm{n} s}$ nonsignificant by the $\mathrm{F}$ test of the analysis of variance. 
Table 6 - Population of plants at 132 days after application (DAA) of the herbicides, mass of 400 grains and yield of maize grains intercropped with Crotalaria juncea, besides the controls without application of herbicide - harvest experiment

\begin{tabular}{|c|c|c|c|c|}
\hline Herbicides/controls & $\begin{array}{l}\text { Dosing } \\
\left(\mathrm{g} \mathrm{ha}^{-1}\right)\end{array}$ & $\begin{array}{l}\text { Population } \\
\text { (a thousand plants } \mathrm{ha}^{-1} \text { ) }\end{array}$ & $\begin{array}{c}\text { Mass of } 400 \\
\text { grains }(\mathrm{g})\end{array}$ & $\begin{array}{c}\text { Yield } \\
\left(\mathrm{kg} \mathrm{ha}^{-1}\right)\end{array}$ \\
\hline 1. Bentazon & 720 & $50.3 \mathrm{abc}$ & $126.5 \mathrm{~cd}$ & $3780 \mathrm{c}$ \\
\hline 2. Bentazon & 960 & $44.1 \mathrm{c}$ & $123.5 \mathrm{~d}$ & $3625 \mathrm{c}$ \\
\hline 3. Nicosulfuron & 16 & $48.7 \mathrm{abc}$ & $149.8 \mathrm{ab}$ & $7128 \mathrm{ab}$ \\
\hline 4. Nicosulfuron & 48 & $55.6 \mathrm{a}$ & $150.5 \mathrm{ab}$ & $7747 \mathrm{ab}$ \\
\hline 5. Bentazon + nicosulfuron & $720+16$ & $50.0 \mathrm{abc}$ & $146.0 \mathrm{ab}$ & $6642 \mathrm{~b}$ \\
\hline 6. Bentazon + nicosulfuron & $720+48$ & $51.3 \mathrm{abc}$ & $150.0 \mathrm{ab}$ & $7473 \mathrm{ab}$ \\
\hline 7. Bentazon + nicosulfuron & $960+16$ & $49.3 \mathrm{abc}$ & $147.5 \mathrm{ab}$ & $7066 \mathrm{ab}$ \\
\hline 8. Bentazon + nicosulfuron & $960+48$ & $50.3 \mathrm{abc}$ & $143.0 \mathrm{abc}$ & $8846 \mathrm{a}$ \\
\hline 9. Maize with weeds & & $54.9 \mathrm{ab}$ & $136.5 \mathrm{abcd}$ & $7199 \mathrm{ab}$ \\
\hline 10. Maize with weeds & & $46.9 \mathrm{abc}$ & $154.0 \mathrm{a}$ & $8152 \mathrm{ab}$ \\
\hline 11. Intercropping with weeds & & $44.4 \mathrm{bc}$ & $131.5 \mathrm{bcd}$ & $2397 \mathrm{c}$ \\
\hline 12. Intercropping with weeds & & $47.1 \mathrm{abc}$ & $117.6 \mathrm{~d}$ & $2406 \mathrm{c}$ \\
\hline $\mathrm{CV}$ & & $8.8^{*}$ & $17.2 * *$ & $14.5 * *$ \\
\hline LSD & & 10.8 & 19.4 & 2174.1 \\
\hline
\end{tabular}

Means followed by the same letter do not differ statistically from each other by the Tukey's test at $5 \%$ probability. **, * Significant at 1 and $5 \%$ probability by the $\mathrm{F}$ test of the analysis of variance.

(summer) than in the late harvest (fall/winter), possibly due to better conditions for vegetative growth of sunn hemp. In addition, the legume would also cause interference in the mechanical harvesting of the grains because of the stem stiffness and plants height, as well as the possible presence of sunn hemp seeds together with the maize kernels.

Based on the results, it was concluded that in maize intercropping with C. juncea, simultaneously sown, the applications of bentazon (720 and $960 \mathrm{~g}$ a.i. ha ${ }^{-1}$ ) in late harvest and of bentazon plus nicosulfuron $\left(720+16\right.$ and $920+16 \mathrm{~g}$ a.i. ha $\left.{ }^{-1}\right)$ in the harvest, provided the best results, considering maize productivity, development and recovery of sunn hemp and weed tillage. Furthermore, bentazon herbicide alone, in both doses tested, was the most selective for $C$. juncea plants; and nicosulfuron at $48 \mathrm{~g}$ a.i. ha ${ }^{-1}$, alone or mixed with bentazon, promoted the best weed control. Maize affected the recoverability of $C$. juncea plants treated with herbicides, as well as the mass accumulation of the legume in intercropping. On the other hand, C. juncea in intercropping without herbicides or sprayed with bentazon had a negative influence on maize productivity in the summer harvest.

\section{REFERENCES}

Amabile R.F., Fancelli A.L., Carvalho A.M. Evaluation of green manures in different sowing dates and row-spacings in the Cerrados region. Pesq Agropec Bras. 2000;35:47-54.

Brow H.M. Mode of action, crop selectivity, and soil relations of the sulfonylurea herbicides. Pestic Sci. 1990;29:263-81.

Galon L. et al. Resistência de Cyperus difformis a herbicidas inibidores da ALS em lavoura de arroz irrigado em Santa Catarina. Planta Daninha. 2008;26:419-27.

Garcia J.M. et al. O gênero Crotalaria L. (leguminosae, faboideae, crotalarieae) na planície de inundação do Alto Rio Paraná, Brasil. Rev Bras Bioci. 2013;11:209-26.

Gitti D.C. et al. Épocas de semeadura de crotalária em consórcio com milho. Rev Bras Milho Sorgo. 2012;11:15668 .

Gronwald J.W., Connelly J.A. Effect of monooxygenase inhibitors on bentazon uptake and metabolism in maize cell suspension cultures. Pestic Biochem Physiol. 1991;40:28494.

Ferreira M.C., Machado Neto J.G., Matuo, T. Redução da dose e do volume de calda nas aplicações noturnas de herbicidas em pós-emergência na cultura da soja. Planta Daninha. 1998;16:25-36. 
Fonne-Pfister R. et al. Hydroxylation of primisulfuron by inducible cytochrome P450 dependent monooxygenase system from maize. Pestic Biochem Physiol. 1990;37:16573.

Fontes J.R.A. et al. Efeitos de herbicidas no controle de plantas daninhas na cultura do feijão-mungo-verde (Vigna radiata L. Wilczek). Ci Agrotec. 2001;25:108796.

Heinrichs R. et al. Produção e estado nutricional do milho em cultivo intercalar com adubos verdes. Rev Bras Cienc Solo. 2002;26:225-30.

Hinz J.R.R., Owen M.D.K., Barret M. Nicosulfuron, primisulfuron, and bentazon hydroxylation by corn (Zea mays), wooly cupgrass (Eriochloa villosa) and shattercane (Sorghum bicolor) cytochrome P-450. Weed Sci. 1997;45:474-80.

Ikeda F.S. et al. Interferências no consórcio de milho com Urochloa spp. Ci Rural. 2013;43:1763-70.

Jakelaitis A. et al. Manejo de plantas daninhas no consórcio de milho com capim-braquiária (Brachiaria decumbens).

Planta Daninha. 2004;22:553-60.

Kappes C. et al. Resposta da crotalária a épocas e subdoses de aplicação de glifosato. Biosci J. 2012;28:373-83.

Mosjidis J.A., Wehtje G. Weed control in sunn hemp and its ability to suppress weed growth. Crop Protec. 2011;30:70-3.

Nakagawa J.A. et al. Consorciação e plantas daninhas afetando a produtividade e a qualidade de sementes de sorgo. Rev Caatinga. 2009;22:45-9.
Oliveira Júnior R.S., Constantin J., Inoue M.H. Seletividade para culturas e plantas daninhas. In: Oliveira Júnior R.S., Inoue M.H., editores. Biologia e manejo de plantas daninhas. Curitiba: Omnipax, 2011. p.243-262.

Santos P.A. et al. Adubos verdes e adubação nitrogenada em cobertura no cultivo do milho. Rev Bras Milho Sorgo. 2010;9:123-34

Santos F.C. et al. Arranjo de plantas de braquiária em consórcio com a cultura do milho. Sete Lagoas: Embrapa Milho e Sorgo, 2014. (Circular técnica, 202).

Silva P.I.B. et al. Corn and brachiaria growth and yield under intercropping system with different weed managements. Planta Daninha. 2014;32:301-9.

Sociedade Brasileira da Ciência das Plantas Daninhas SBCPD. Procedimentos para instalação, avaliação e análise de experimentos com herbicidas. Londrina: 1995. 42p.

Telhado S.F.P. Desempenho e produtividade de milho em consórcio com adubos verdes em sistema orgânico de produção [dissertação]. Piracicaba: Escola Superior de Agricultura "Luiz de Queiroz", 2007.

Timossi P.C., Freitas T.T. Eficácia de nicosulfuron isolado e associado com atrazine no manejo de plantas daninhas em milho. Rev Bras Herbic. 2011;10:210-8.

Timossi P.C. et al. Supressão de plantas daninhas e produção de sementes de crotalária, em função de métodos de semeadura. Pesq Agropec Trop. 2011;41:525-30.

Wang K., Sipes B.S., Schimitt D.P. Crotalaria as a cover crop for nematode management: A review. Nematropica. 2002;32:35-57. 